\title{
A Novel Low-Cost Method of Manufacturing Nb3Sn Superconductors with Multiple-Tin-Tube Sources
}

\section{Cooperative Research and Development Agreement Final Report}

\section{CRADA Number: FRA-2008-0001}

\section{Fermilab Technical Contact: Emanuella Barzi}

Summary Report

21 May 2012 


\section{NOTICE}

This report was prepared as an account of work sponsored by an agency of the United States government. Neither the United States government nor any agency thereof, nor any of their employees, makes any warranty, express or implied, or assumes any legal liability or responsibility for the accuracy, completeness, or usefulness of any information, apparatus, product, or process disclosed, or represents that its use would not infringe privately owned rights. Reference herein to any specific commercial product, process, or service by trade name, trademark, manufacturer, or otherwise does not necessarily constitute or imply its endorsement, recommendation, or favoring by the United States government or any agency thereof. The views and opinions of authors expressed herein do not necessarily state or reflect those of the United States government or any agency thereof.

Available electronically at http://www.osti.gov/bridge

Available for a processing fee to U.S. Department of Energy and its contractors, in paper, from:

U.S. Department of Energy Office of Scientific and Technical Information

P.O. Box 62

Oak Ridge, TN 37831-0062

phone: 865.576 .8401

fax: 865.576 .5728

email: mailto:reports@adonis.osti.gov

Available for sale to the public, in paper, from:

U.S. Department of Commerce

National Technical Information Service

5285 Port Royal Road

Springfield, VA 22161

phone: 800.553 .6847

fax: 703.605.6900

email: orders@ntis.fedworld.gov

online ordering: http://www.ntis.gov/ordering.htm

May 2012 
In accordance with Requirements set forth in Article XI.A(3) of the CRADA document, this document is the final CRADA report, including a list of Subject Inventions, to be forwarded to the Office of Science and Technical Information as part of the commitment to the public to demonstrate results of federally funded research.

CRADA number: $\quad$ FRA-2008-0001

CRADA Title: $\quad$ A Novel Low-Cost Method of Manufacturing Nb3Sn

Superconductors with Multiple-Tin-Tube Sources

Parties to the Agreement: SupraMagnetics, Inc. and Fermi Research Alliance, LLC

\begin{abstract}
CRADA work:
In order to successfully sustain a fusion reaction, peak magnetic fields on the order of 12-13 Tesla will be required. Magnetic fields of this magnitude can only be accomplished by advanced superconductors such as Nb3Sn. However, the economic success of a fusion machine will depend on further improvements in the cost-performance of the Nb3Sn conductor. This project will develop a novel, low-cost, multiple-tin-tube process as a new manufacturing approach for large-scale $\mathrm{Nb3Sn}$-conductor production. The process will be suitable for the efficient production of larger strands $(0.83 \mathrm{~mm})$, consistent with ITER (International Thermonuclear Experimental Reactor) specifications.
\end{abstract}

In Phase I, $\mathrm{Cu} / \mathrm{Nb}$ composites were manufactured and shaped into sub-elements. These subelements were tin-coated by electroplating, assembled into a precise-fit restack billet tube, and drawn to $0.83 \mathrm{~mm}$ diameter.

In Phase II, the process will be scaled-up to full production levels. The improved Nb3Sn conductor should have an immediate benefit for high-field magnet applications. A prototype fusion machine, based on a cost effective Nb3Sn conductor, would have enormous economic and social benefits. In addition, the conductor should be applicable to nuclear magnetic resonance (NMR), which has requirements for use in chemical research, biochemistry, pharmaceutical chemistry, polymer science, petroleum research, agricultural chemistry, and medicine.

Leszek Motowidlo, Principal Investigator, will be responsible for the overall coordination of the effort. He and others of SupraMagnetics staff will design and fabricate protoype PIT Nb3Sn conductors for evaluation at Fermilab. Emanuela Barzi will be responsible for the Fermilab subcontract and will coordinate and supervise critical current testing Nb3Sn strands and cable fabrication and evaluation.

This work was funded by DOE SBIR Award DE-FG02-06ER84447.

May 2012 


\section{Summary of Research Results:}

This project was performed in parallel to DOE SBIR Award DE-FG02-06ER84442 (see Final Report for CRADA FRA-2008-0002).

The report has not been made publicly available but can be requested from OSTI.

The results of the project influenced a series of follow-on projects, eventually resulting in U.S. Patent 9,385,295 B2, filed on August 7, 2009 and issued July 5, 2016.

Related Reports, Publications, and Presentations:

Leszek R. Motowidlo. Novel Low-Cost Method of Manufacturing Nb3Sn Multifilamentary Superconductors with Multiple-Tin-Sources. United States: N. p., 2012. Web (OSTI Identifier 1040713).

\section{Subject Inventions listing:}

None

Report Date: 21 May 2012

\section{Technical Contact at Fermilab: Emanuella Barzi}

This document contains NO confidential, protectable or proprietary information. 